\author{
Gregório, P. H. S. - O trágico em "Augusto Matraga"
}

\title{
trágico em $A$ hora e a vez de Augusto Matraga: uma leitura nietzschiana
}

\author{
Paulo Henrique da Silva Gregório ${ }^{1}$
}

\begin{abstract}
This article presents a study of the short story "A hora e a vez de Augusto Matraga", by Guimarães Rosa, which investigates how the tragic appears in this literary work and how it might represent a redemption signal to the main character. The study is based on Nietzsche's concept of the tragedy, constituted by the fusion between two opposite impulses. They are related to Apollo and Dionysus' spirits that represent appearance and essence, respectively.
\end{abstract}

Keywords: Nietzsche; the tragic; "A hora e a vez de Augusto Matraga”; Guimarães Rosa.

Resumo: Neste artigo é feito um estudo do conto "A hora e a vez de Augusto Matraga", de Guimarães Rosa, de modo a se observar como o trágico manifesta-se nessa obra e como ele pode representar um sinal de salvação para a personagem principal. Tal estudo está ancorado na concepção de trágico nietzschiana, segundo a qual a tragédia se constitui a partir da fusão de duas forças opostas, referentes aos espíritos de Apolo e Dioniso, representantes da aparência e da essência, respectivamente.

Palavras-chave: Nietzsche; trágico; “A hora e a vez de Augusto Matraga”; Guimarães Rosa.

O trabalho com a linguagem empreendido por Guimarães Rosa em suas obras, por meio do qual ele cria neologismos e uma sintaxe que, muitas vezes, não corresponde ao padrão culto da língua portuguesa, costuma ser considerado o seu traço sui generis. Dado esse aspecto, é possível ter uma noção acerca das dificuldades com as quais se depararam os tradutores da obra desse autor, tendo em vista a impossibilidade de se

\footnotetext{
${ }^{1}$ Mestrando em Estudos da Linguagem na Universidade Federal do Rio Grande do Norte. Email: paulohenrich@yahoo.com.br
} 


\section{Gregório, P. H. S. - O trágico em "Augusto Matraga"}

transpor, em muitos casos, estruturas sintáticas ou mesmo certas expressões para outro idioma. Curt Meyer-Clason - considerado por Rosa "um gênio da tradução" (LORENZ 1991: 71), o melhor que ele conhecera - chega a afirmar que a "recriação dos inúmeros neologismos do autor de Grande sertão, às vezes realizável, às vezes irrealizável, seria tema para um livro ou para um seminário para estudantes bilíngües.” (CHIAPPINI 2002: 371, grifos da autora). Meyer-Clason aponta ainda que traduzir Rosa significa "solicitar a ajuda de todas as forças da imaginação; colocar em campo uma tropa inteira de faculdades imaginativas; tentar aqui e acolá pregar uma peça no autor, superar-lhe num ponto e por vezes registrar uma vantagem.” (BUSSOLOTTI 2003: 153).

A produção ficcional rosiana foi traduzida para vários idiomas, dentre os quais podem ser apontados, além do alemão, o inglês, o italiano e o francês. A preferência pela tradução alemã estava relacionada não só ao trabalho realizado por Meyer-Clason, mas também ao próprio fato de que o idioma alemão, segundo o autor, era o "mais apto a captar e refletir todas as nuances da língua e do pensamento" em que tentou "vazar" os seus livros (apud BussolotTi 2003: 70). Assim, em correspondências trocadas com Meyer-Clason, Rosa fazia questão de acompanhar o processo de tradução, dando sugestões, apontando equívocos, enfim, empreendendo esforços para que sua obra pudesse ter uma recepção positiva por parte dos leitores da Alemanha, país onde atuou como cônsul-adjunto, entre 1938 e 1942.

De fato, a recepção na Alemanha foi bastante considerável, tanto que Grande Sertão teve três edições esgotadas no mesmo ano em que foi lançado, 1964. Dentre os críticos que se posicionaram diante do lançamento dessa obra está Günter Lorenz, que, numa crítica publicada na revista Humboldt, elogia a obra e enaltece o autor, considerando-o "herdeiro legítimo de Joyce e Proust, de Thomas Mann e Faulkner, e, desde o aparecimento de seu primeiro romance traduzido, candidato ao Prêmio Nobel de Literatura." (apud BusSOLOTTI 2003: 380). Meyer-Clason, por sua vez, atenta para a questão da dificuldade de acesso à obra rosiana pelos leitores da Alemanha, embora, de acordo com o tradutor, "as versões alemãs estivessem [...] mais acessíveis ao leitor alemão do que as portuguesas ao leitor brasileiro." (apud BussolotTi 2003: 50). Mesmo assim, depois de Grande Sertão, ainda foram publicados nesse país os livros 


\section{Gregório, P. H. S. - O trágico em "Augusto Matraga"}

Corps de Ballet (1966), Das dritte Ufer des Flusses (1968), Mein Onkel der Jaguar (1981) e Sagarana (1982).

A despeito do apontamento de Meyer-Clason, a linguagem "difícil" de Guimarães Rosa não impediu sua boa receptividade por parte dos leitores brasileiros. $\mathrm{Na}$ verdade, a projeção do autor em outros países parece ser oriunda da dimensão que sua obra atingiu, primeiro, no Brasil, onde começou a ser prestigiado enquanto literato a partir de publicação de seu primeiro livro, Sagarana. CANDIDO (1991: 245), ressaltando o valor dessa obra, afirma que ela "nasceu universal pelo alcance e pela coesão da fatura". Dos contos que integram essa coletânea, ele considera "A hora e a vez de Augusto Matraga", no qual se centrará a abordagem do presente estudo, a "obra-prima do livro", tendo em vista que Rosa, "deixando de certo modo a objetividade da artepela-arte, entra em região quase épica de humanidade e cria um dos grandes tipos de nossa literatura" (CANDIDO 1991: 247).

A tradução de "A hora e a vez de Augusto Matraga" para outros idiomas representou o marco inicial da divulgação de Guimarães Rosa em outros países, o que parece ser um indício da posição de destaque que esse conto ocupa em meio à produção ficcional rosiana. Nele, o autor traz à tona a história de Nhô Augusto Esteves, um homem de prestígio que, depois de ser abandonado pela esposa e espancado pelos próprios capangas, passa a ter como única opção o refúgio e a adoção de uma vida de penitência, em prol da própria salvação. Sob os cuidados de um casal de negros, passa a viver no povoado do Tombador, lugar distante de onde residia inicialmente, permanecendo lá durante muito tempo, rezando, trabalhando para ajudar aos outros, até que decide partir em busca daquilo que seria a sua "hora" e "vez". Sob a guia de um jegue, chega a um povoado chamado Rala-Coco, onde encontra Joãozinho Bem-Bem, contra quem combate em favor de um homem que estava prestes a ser assassinado pelo outro. Depois de mortalmente ferido, é aclamado pela coragem de haver enfrentado Bem-Bem, bandido temido naquela região, e passa, assim, a ser considerado um santo.

A trajetória da personagem costuma ser dividida em três fases: na primeira, é posto em relevo o seu comportamento libertino e desenfreado; na segunda, observa-se a mudança de postura e o desejo de buscar a salvação para a alma; por fim, no estágio em que parte em busca de sua "hora" e "vez", é impelido a agir em função de dois 


\section{Gregório, P. H. S. - O trágico em "Augusto Matraga"}

impulsos, relacionados às outras duas fases, e que se manifestam de modo equilibrado. Essa divisão tripartível é sugerida logo no início da narrativa, quando o narrador se refere à personagem desta maneira: "Matraga não é Matraga, não é nada. Matraga é Esteves. Augusto Estêves, filho do Coronel Afonsão Esteves, das Pindaíbas e do Sacoda-Embira. Ou Nhô Augusto - o homem" (RosA 2001: 363). Ou seja: Augusto Esteves, Nhô Augusto e Matraga são nomes que estão associados ao perfil assumido pela personagem naquelas três fases, respectivamente. Nesse sentido, a observação de cada uma delas vai servir de ponto de partida para o estudo aqui proposto, cujo objetivo é analisar, primeiro, como o trágico se instala no conto, e, por fim, de que forma o trágico pode representar um fator por meio do qual a personagem atinge a própria libertação.

Antes que se parta para o estudo propriamente dito do texto, faz-se necessário tecer algumas considerações sobre a concepção de trágico elaborada por Nietzsche, na qual está ancorado o presente estudo. Em seus escritos acerca da origem da tragédia grega, ele afirma que "o contínuo desenvolvimento da arte está ligado à duplicidade do apolíneo e do dionisíaco, da mesma maneira como a procriação depende da dualidade dos sexos, em que a luta é incessante e onde intervêm periódicas reconciliações" (NIETZSCHE 1992: 27, grifos do autor). Nesse sentido, embora se mantenham em constante estado de confronto, esses dois instintos podem vir a se emparelhar e, desse emparelhamento, geram a obra que será ao mesmo tempo apolínea e dionisíaca: a tragédia ática. Portanto, de acordo com essa concepção nietzschiana, o trágico se constitui a partir da fusão de traços inerentes a cada um daqueles dois espíritos.

Com relação a esses traços, dos quais trataremos mais adiante, é possível associá-los às fases da trajetória da personagem de "A hora e a vez de Augusto Matraga”, ou seja, tendo em vista os caracteres próprios das entidades Dioniso e Apolo, partiremos da ideia de que Nhô Augusto Esteves vive uma fase dionisíaca, uma apolínea, e outra, ainda, em que as duas se entrecruzam. Seguindo esse tripé, serão analisadas, separadamente, as duas primeiras, para que, por fim, possa ser percebido como elas se fundem na terceira fase da personagem, de modo a instalar o trágico no conto.

A inserção das obras de Guimarães Rosa na problemática referente ao trágico é algo recorrente na fortuna crítica do autor. Consuelo ALBERGARIA, por exemplo, no 


\section{Gregório, P. H. S. - O trágico em "Augusto Matraga"}

ensaio "O sentido do trágico em 'A terceira margem do rio", traça um paralelo entre a "unidade de ação" desse conto "e a do teatro grego clássico" (AlBERGARIA 1991: 523), identificando como trágico o estado de imobilidade das personagens, o qual se assemelha ao de outras, como Prometeu e Io, de Prometeu acorrentado. Trabalhando com essa mesma obra, Eduino ORIONE parte de uma associação entre ela e o drama barroco alemão, e, uma vez identificados na personagem principal aspectos como a melancolia - "marca distintiva do herói trágico barroco", segundo ORIONE (2008: 69) -, afirma-se que Rosa empreende, no referido conto, uma reelaboração do drama barroco. Outro estudo relevante a ser apontado é o de Ettore FINAZZI-AGRÒ que, em sua análise de Grande Sertão: veredas, assinala que o trágico reside em uma aporia inerente a esta obra. Tal aporia estaria relacionada à posição de neutralidade assumida por Riobaldo, tendo em vista o caráter dúbio de sua individualidade - neutralidade cujo resultado é o que o autor denomina "suspensão trágica" (FINAZZI-AGRò 2002: 125). ${ }^{2}$

Assim, podemos passar para o estudo do conto. Em se tratando de uma análise de cunho literário, o elemento central será o texto rosiano, em detrimento de considerações de ordem teórico-conceitual, pois estas apenas fornecerão bases para que se possa compreender de forma coerente a problemática do trágico na obra literária em questão.

\section{Augusto Esteves e o furor dionisíaco}

A primeira fase da personagem vai do início da narrativa até o ponto em que é espancada e marcada com ferro em brasa pelos capangas do Major Consilva, atirandose, logo em seguida, de um penhasco. Já em sua primeira aparição no conto, Augusto Esteves é apresentado pelo narrador como um homem de índole imperativa, que impunha a sua superioridade aos habitantes do povoado do Murici. O respeito e até certo temor que estes lhe destinavam eram devidos não só à posição de destaque da qual gozava em decorrência da posse de muitos bens, como fazendas e terras, mas também

\footnotetext{
${ }^{2}$ É válido mencionarmos, também, as dissertações de mestrado elaboradas por Eduardo LEITÃo (2006) e Ana CostA (2006), nas quais se analisa o conto "A hora e a vez de Augusto Matraga", de modo a associá-lo ao mito de Apolo e Dioniso, embora a ênfase não seja dada à questão do trágico.
} 


\section{Gregório, P. H. S. - O trágico em "Augusto Matraga"}

ao modo violento com que costumava agir quando eram impostos empecilhos aos seus objetivos. No fragmento abaixo, ele aparece determinado a arrematar uma prostituta exposta em um leilão.

E, aí, de repente, houve um deslocamento de gentes, e Nhô Augusto, alteado, peito largo, vestido de luto, pisando pé dos outros e com braço em tenso, angulando os cotovelos, varou a frente da massa, se encarou com a Sariema, e pôs-lhe o dedo no queixo. Depois, com voz de meio-dia, berrou para o leiloeiro Tião:

- Cinqüenta mil-réis!... (ROSA, 2001: 364).

Ele se desloca em meio ao povo tal qual um animal disposto a agarrar sua presa. $\mathrm{O}$ modo como age diante da Sariema, que parece indicar a supremacia do predador diante da fragilidade da presa, bem como o berro que solta para o leiloeiro revelam instintos primitivos, animalescos, da individualidade da personagem. É devido a esse temperamento, dominante em toda essa primeira fase, que é possível caracterizá-la como dionisíaca, tomando por base os pressupostos nietzschianos. Para NiETzSCHE (1992: 35), no estado dionisíaco "o homem é incitado à máxima intensificação de todas as suas capacidades simbólicas; algo jamais experimentado empenha-se em exteriorizarse". Assim, o indivíduo se sente livre para fazer uso de todas as suas potencialidades, não obedecendo a leis, regras ou qualquer coisa que possa servir de aprisionamento para o espírito que deseja experimentar o novo. Conforme assinala BRANDÃo (1991: 140, grifos do autor), "o deus da mania e da orgia configura a ruptura das inibições, das repressões e dos recalques. [...] Dioniso retrataria as forças de dissolução da personalidade: a regressão às forças caóticas e primordiais da vida". Nessa perspectiva, observemos em que aspectos essas forças agem sobre Nhô Augusto Esteves, impulsionando-o a agir dionisiacamente.

O primeiro a ser apontado diz respeito ao modo desregrado e libertino como ele se portava em todos os âmbitos de sua vida. No fragmento que segue, o narrador aponta os principais traços característicos da individualidade da personagem:

E ela [Dinória] conhecia e temia os repentes de Nhô Augusto. Duro, doido e sem detença, como um bicho grande do mato. E, em casa, sempre fechado em si. Nem com a menina se importava. Dela, Dinória, gostava, às vezes; da sua 


\section{Gregório, P. H. S. - O trágico em "Augusto Matraga"}

boca, das suas carnes. Só. No mais, sempre com os capangas, com mulheres perdidas, com o que houvesse de pior. Na fazenda - no Saco-da-Embira, nas Pindaíbas, ou no retiro do Morro Azul - ele tinha outros prazeres, outras mulheres, o jogo do truque e as caçadas. (RosA 2001: 368-369).

A comparação feita entre o comportamento de Nhô Augusto e o de um "bicho" corrobora a ideia de que havia um instinto animalesco impregnado na natureza do seu ser. Nesse sentido, tal qual animal livre que é aprisionado, sentia-se insatisfeito quando se via em casa, uma vez que o verdadeiro prazer era encontrado na vida de libertinagem junto aos capangas e às prostitutas, ou quando ia "em busca de qualquer luz em porta aberta, aonde houvesse assombro de homens, para entrar no meio ou desapartar" (RosA 2001: 368), esbanjando sua valentia. Tal conduta pode ser compreendida como um "berro" contra qualquer tipo de repressão ao seu desejo de experimentar sensações, próprio do espírito de Dioniso. Segundo BRANDÃO (1985: 11, grifos do autor), “o homo dionysiacus, integrado a Dioniso, através do êxtase e do entusiasmo, se libera de certos condicionamentos e interditos de ordem ética, política, e social." Nesse sentido, uma vez em desacordo com os ditames impostos pelo mundo, a personagem parece estar permanentemente extasiada, como se vivesse em constante estado de embriaguez. LIMA (2006: 49) assinala que Dioniso é a "divindade que expõe o homem ao suplício, oferecendo-lhe, em contrapartida, a alegria orgiástica da embriaguez."

Outra característica que revela o modo de ser dionisíaco de Augusto Esteves é o seu impulso para matar. "Para isso, sim, ele prestava muito" (RosA 2001: 369), conforme assinala o narrador. Mas é preciso esclarecer que a manifestação do espírito de Dioniso não se dá no próprio ato de matar, e sim nos fatores que levam a personagem a querer fazê-lo, geralmente agindo por vingança, em consonância com os seus instintos. Por causa destes é que ele não hesita levar à morte alguém que, por exemplo, tenha ameaçado a sua honra, ou então contrariado seus desígnios, como foi o caso do abandono por parte da mulher e dos capangas, deixando-o furioso e decidido a fazer o acerto de conta com todos eles, como podemos perceber no trecho abaixo:

Nele, mal-e-mal, por debaixo da raiva, uma idéia resolveu por si: antes de ir à Mombuca, para matar o Ovídio e a Dinória, precisava de cair com o Major 


\section{Gregório, P. H. S. - O trágico em "Augusto Matraga"}

Consilva e os capangas. Se não, se deixasse o resto por acertar, perdia a força. E foi. (ROSA 2001: 373).

$\mathrm{O}$ aspecto instintivo da personagem fica evidente nesse trecho. Assim como um predador, que ao devorar a sua presa o faz por necessidade, pois precisa do alimento, Nhô Augusto mata não porque seja mau, mas para não perder a força, a honra, numa briga em que seus concorrentes haviam se apropriado daquilo que era seu e, por esse motivo, não admitia sair em desvantagem da disputa. O Quim Recadeiro, diante da resolução tomada pelo seu senhor, faz questão de alertá-lo acerca dos perigos aos quais estava exposto, tendo em vista os comentários que eram feitos a respeito dele: "estão dizendo que o senhor nunca respeitou filha dos outros nem mulher casada, e mais que é que nem cobra má, que quem vê tem de matar por obrigação...” (RosA 2001: 373). Mais uma vez a conduta da personagem é comparada à de um animal, no caso, uma cobra, a qual, sendo "má" - expressão utilizada provavelmente para fazer menção às espécies peçonhentas -, deve ser morta por aquele que, por desventura, cruze o seu caminho, pois sua natureza determina que assim proceda. Nesse sentido, assim como ela dispõe da peçonha, ele tem a habilidade para matar, da qual se utiliza conforme seus instintos vingativos determinem.

Enquanto queria se vingar da esposa, dos capangas e do Major Consilva, este último almejava o mesmo em relação a ele, tendo articulado, para tanto, um modo de tirar-lhe a vida. Percebemos aí um embate entre duas forças marcadamente dionisíacas, mas, dessa vez, a supremacia de Augusto Esteves foi sobreposta pelo poderio do Major, que, por intermédio daqueles mesmos capangas, deixou o outro entre a vida e a morte, embora acreditasse ter dado fim à existência dele, como podemos verificar no seguinte fragmento:

O Major, lá da varanda, apertando muito os olhos, para espiar, e se abanando com o chapéu, tirou ladainha:

- Não tem mais nenhum Nhô Augusto Esteves, das Pindaíbas, minha gente?

E os cacundeiros em coro:

- Não tem não! Tem mais não!... (RoSA 2001: 375).

A resposta dada pelos capangas assinala o fim dessa fase dionisíaca, selada com a marca de ferro em brasa impressa no corpo de Nhô Augusto. Ele, como "era couro ainda por 


\section{Gregório, P. H. S. - O trágico em "Augusto Matraga"}

curtir” (ROSA 2001: 373), ao invés de se entregar à morte, atira-se no penhasco, pois, na situação que se encontrava, não temia uma desgraça maior. Essa queda pode ser interpretada como um símbolo da mudança que acontecerá na vida dele, que, destituído de seu posto de dominador, desonrado, abandonado pela mulher e pelos capangas, passa a enxergar como única alternativa a adoção de uma nova forma de viver, completamente oposta à anterior, ao encontro da qual ele se lançava.

\section{Nhô Augusto sob o manto apolíneo}

Depois que se atira no penhasco e é encontrado pelo preto, Nhô Augusto inicia a sua fase apolínea. Ao invés de buscar a vingança contra os inimigos, volta-se para si, refletindo sobre suas atitudes, pensando na esposa e na filha, das quais passou a sentir saudades, consciente de que as tinha perdido para sempre. Com a sensação de ter caído "num fundo de abismo, em outro mundo distante" (RosA 2001: 378), ele passa a recorrer a Deus, mostrando-se frágil, necessitado do auxílio de uma força superior, desejando, inclusive, ser absolvido dos pecados. Foi quando o casal de pretos trouxe um padre para visitá-lo, com quem pôde conversar e se confessar, recebendo orientações de como dar prosseguimento à vida, as quais foram decisivas para essa sua nova fase. $\mathrm{O}$ padre recomendou-lhe que esquecesse a mulher, renunciasse à vingança, fizesse penitência, trabalhasse em prol dos outros, e acrescentou: "Modere esse mau gênio: faça de conta que ele é um poldro bravo, e que você é mais mandante do que ele...” (RosA 2001: 380). Por fim, o reverendo proferiu as últimas palavras, as quais ficaram incrustadas na mente de Nhô Augusto:

- Reze e trabalhe, fazendo de conta que esta vida é um dia de capina com sol quente, que às vezes custa muito a passar, mas sempre passa. E você ainda pode ter muito pedaço bom de alegria... Cada um tem a sua hora e a sua vez: você há de ter a sua. (ROSA 2001: 380).

Assim, em busca da sua "hora" e "vez", Nhô Augusto passa a agir apolineamente, domando o seu "mau gênio", ou seja, aprisionando o espírito de Dioniso sob o véu de Apolo, “deus da individuação, do sonho e da ilusão, da aparência e da arte plástica" 


\section{Gregório, P. H. S. - O trágico em "Augusto Matraga"}

(PERRUSI 2000: 9), propiciador de "um comedimento e equilíbrio que lhe são próprios" (LimA 2006: 50). Mudando-se para o povoado do Tombador, "onde, às vezes, pouco às vezes e somente quando transviados de boa rota, passavam uns bruaqueiros tangendo tropa, ou uns baianos corajosos migrando rumo sul” (ROSA 2001: 382), começa uma nova vida, longe de tudo o que pudesse desviá-lo do seu ideal de salvação. Esse isolamento no âmbito do espaço físico reflete o próprio ato da personagem de se voltar para si, reconciliando-se com o próprio ser, entrando em consonância com o principium individuationis apolíneo. Nesse sentido, Nhô Augusto, embora trabalhasse incansavelmente em benefício dos outros, não esquecia em momento nenhum de si mesmo, daquele seu ideal. A propósito, todo o esforço que empreendia nos trabalhos estava diretamente atrelado à esperança de que sua "hora" chegaria, pois esse era o caminho para alcançá-la, conforme recomendara o padre. Nem mesmo no dia dedicado ao descanso ele ficava ocioso, sempre ocupando o tempo com alguma atividade, como podemos observar no fragmento que segue.

\footnotetext{
Nos domingos, tinha o seu gosto de tomar descanso: batendo mato, o dia inteiro, sem sossego, sem espingarda nenhuma e nem nenhuma arma para caçar; e, de tardinha, fazendo parte com as velhas corocas que rezavam o terço ou os meses dos santos. Mas fugia às léguas de viola ou sanfona, ou de qualquer outra qualidade de música que escuma tristezas no coração. (RoSA 2001: 382-383).
}

Embora aparentemente satisfeito com a nova vida, Nhô Augusto não dá espaço para que certas lembranças provenientes de sua fase dionisíaca venham à tona, por isso foge das sanfonas e violas. Ele parece temer que aquele velho instinto surja das profundezas do seu ser, como a fênix renasce das cinzas, levando-o novamente à perdição. Nesse novo estágio, o princípio de individuação apolíneo, manifestado na busca pela própria "hora", é o único meio que Nhô Augusto tem para garantir a sua existência, pois para ele "a vida já se acabara, e só esperava era a salvação da sua alma e a misericórdia de Deus Nosso Senhor. Nunca mais seria gente!” (RosA 2001: 380). Conforme aponta MACHADO (2005: 7) os “deuses e heróis apolíneos são aparências artísticas que tornam a vida desejável, encobrindo o sofrimento pela criação de uma ilusão. Essa ilusão é o princípio de individuação.” Assim, apesar de ter rompido com o estado dionisíaco, este não se extingue, mas permanece na personagem em estado latente, subjugado pela força 


\section{Gregório, P. H. S. - O trágico em "Augusto Matraga"}

apolínea. Para Benchimol (2002: 67, grifo do autor), o triunfo de Apolo representa uma "imposição da medida à massa instintiva, e da submissão desta ao império de uma única vontade ordenadora e direcionadora". Em consonância com essas ideias, MACHADO (2001: 97) afirma que "o saber apolíneo evidencia-se parcial, ao deixar de lado algo que não pode ser ignorado fatalmente e que se impõe: a outra força artística que brota da natureza, o dionisíaco." Apolo seria, assim, "sempre ulterior, no sentido de irromper justamente para conter o caráter arrebatador" de Dioniso (LIMA 2006: 55).

Enquanto se individualiza, desvinculando-se, desse modo, do universo no qual estava inserido enquanto homem dionisíaco, Nhô Augusto passa por um processo de mutilação da sua própria essência, precisando renunciar a tudo o que, por instinto, era habituado a praticar. Tal processo pode ser interpretado como um sinal da situação de declínio em que se encontrava a personagem, tendo em vista que o seu esforço para manter o instinto dionisíaco sob o jugo apolíneo parece gerar sofrimento. Nesse caso, podemos conceber como desditosa a situação da personagem, a qual parece consciente de que está destinada a conviver com um conflito interno entre dois instintos completamente opostos até que chegue a sua "hora". Conforme assinala LESKY (1976: 21), na situação trágica "há as forças contrárias, que se levantam para lutar umas contra as outras, há o homem, que não conhece a saída da necessidade do conflito e vê sua existência abandonada à destruição."

Mesmo fugindo das situações que pudessem conduzi-lo àquela fase inicial, certo acontecimento serviu para atiçar o instinto dionisíaco de Nhô Augusto: a visita de Tião. Este trouxe notícias sobre Dinória, Mimita, o Major Consilva e até o Quim, as quais em nada lhe agradaram. A primeira ainda estava vivendo com Ovídio, pensando até em casar; a filha havia se tornado prostituta; o Major se apropriara de algumas de suas terras; e o Quim morrera baleado por tentar vingar a "morte" do patrão. Com o espírito abalado, Nhô Augusto tentava se revestir da armadura apolínea, repetindo a jaculatória ensinada pelo padre, de modo a conter o ameaçador furor de Dioniso, mas isso pouco adiantou, pois

[...] daí em seguida, ele não guardou mais poder para espantar a tristeza. E, com a tristeza, uma vontade doente de fazer coisas mal-feitas, uma vontade sem calor no corpo, só pensada: como que, se bebesse e cigarrasse, e ficasse sem 


\section{Gregório, P. H. S. - O trágico em "Augusto Matraga"}

trabalhar nem rezar, haveria de recuperar sua força de homem e seu acerto de outro tempo, junto com a pressa das coisas, como os outros sabiam viver. (ROSA 2001: 385).

A partir de então, seus instintos dionisíacos começam novamente a se manifestar, embora timidamente, por meio da vontade de "fazer coisas mal-feitas" e também no modo como passou a se lamentar de sua condição, consciente de que, apesar de haver perdido tudo, inclusive a honra, encontrava-se desprovido de sua "força de homem e seu acerto de outro tempo", não lhe restando outra alternativa senão a vida de penitência. A personagem conhece suas potencialidades, das quais se utilizava libertinamente outrora, e se entristece diante do fato de que foram reduzidas a apenas um ideal, o da busca pela "hora". Em diálogo com a preta Quitéria, ele expressa sua tristeza: "Já fiz penitência esses anos todos, e não posso ter prejuízo deles! Se eu quisesse esperdiçar essa penitência feita, ficava sem uma coisa nem outra... Sou um desgraçado, mãe Quitéria, mas o meu dia há-de-chegar!...” (RosA 2001: 387).

Como se não bastasse a visita de Tião, outro evento surge para reavivar ainda mais o ânimo dionisíaco da personagem: a chegada de Joãozinho Bem-Bem e seu bando no povoado do Tombador. Enquanto o povo se aterrorizava com a presença dos visitantes, Nhô Augusto não hesitou se aproximar deles e lhes oferecer abrigo. Assim, dedicou todos os esforços para proporcionar aos hóspedes o que havia de melhor em sua casa, contentando-se em receber, como recompensa, momentos de conversa, nos quais se deleitava com as narrativas contadas pelos parceiros de Bem-Bem. Além disso, contemplava admirado o vigor físico daqueles homens, e, não se contendo, apalpavalhes os braços, como se, por meio daquele contato pudesse restituir a sua força, a sua "homência" (RosA 2001: 385). Tomado pela euforia dionisíaca, teve, em certo momento, um sobressalto, expressando-se tal qual um verdadeiro chefe de jagunços, como podemos verificar neste fragmento:

- Opa! Ôi-ai!... A gente botar você, mais você, de longe, com as clavinas... E você outro, aí, mas este compadre de cara séria, p'ra voltearem... E este companheirinho chegador, pra chegar na frente, e não dizer até logo!... E depois chover sem chuva, com o pau escrevendo e lendo, e arma de fogo debulhando, e homem mudo gritando, e os do-lado-de-lá correndo e pedindo perdão!... (ROSA 2001: 394). 


\section{Gregório, P. H. S. - O trágico em "Augusto Matraga"}

Esses ímpetos de euforia eram observados por Joãozinho Bem-Bem, que, antes de partir, pôs em xeque aquela identidade beata assumida pelo outro: “- Mano velho, o senhor gosta de brigar, e entende. Está-se vendo que não viveu sempre aqui nessa grota, capinando roça e cortando lenha... [...] Quer se amadrinhar com meu povo? Quer vir junto?" (Rosa 2001: 396). Assim, com esse convite, o chefe do bando, como homem dionisíaco que era, revela sua capacidade de lançar "um olhar verdadeiro à essência das coisas" (NIETZSCHE 1992: 56), e reconhece no "mano velho" um espírito semelhante ao seu, dotado dos requisitos necessários para que pudesse acompanhá-lo nas aventuras pelo sertão. Nessa perspectiva, a vida de penitência assumida por Nhô Augusto pode ser interpretada como um meio de que ele se utilizava para suportar a vergonha que sentia de si mesmo e, desse modo, "esperar melhor, mais sem pressa, a hora da libertação." (RosA 2001: 389). Para atingir tal ideal, era preciso domar seus instintos, velar sua verdadeira essência, pois não dispunha mais da "homência" de outrora para poder agir dionisiacamente. Portanto, assumir a aparência de homem penitente era, antes de tudo, uma necessidade, pois o ser verdadeiro, o "Uno-primordial", enquanto "eternopadecente e pleno de contradição necessita, para a sua constante redenção, também da visão extasiante, da aparência prazerosa", conforme assinala NIETZSCHE (1992: 39).

Depois do convite de Joãozinho Bem-Bem, passou a ser dominado de modo mais intenso por essa euforia. Parece que o chamado do chefe - uma mostra de que confiava na força do outro - serviu para restabelecer paulatinamente sua autoconfiança. Assim, sentindo-se mais forte, começava a ter certa repulsa pela situação em que permanecia desde muito tempo, conforme podemos perceber no fragmento seguinte, em cujo início o narrador faz referência a Bem-Bem e seus homens:

Aqueles, sim, que estavam no bom, porque não tinham de pensar em coisa nenhuma de salvação de alma, e podiam andar no mundo, de cabeça em pé... Só ele, Nhô Augusto, era quem estava todo desonrado, porque, mesmo lá, na sua terra, se alguém se lembrava ainda do seu nome, havia de ser para arrastá-lo pela rua da amargura... (RosA 2001: 397). 


\section{Gregório, P. H. S. - O trágico em "Augusto Matraga"}

A retomada do vínculo com as lembranças do passado incitava ainda mais os seus instintos primitivos, os quais passaram a se fortalecer num movimento crescente, manifestando-se em alguns comportamentos da personagem, como a saudade que voltou a sentir das mulheres, a retomada do hábito de fumar e o modo mecânico como passou a proferir a frase "cada um tem sua hora, e há de chegar a minha vez!" (RosA 2001: 398). Certa noite, teve um sonho "no qual havia um Deus valentão, o mais solerte de todos os valentões, assim parecido com seu Joãozinho Bem-Bem, e que o mandava ir brigar, só para lhe experimentar a força” (ROSA 2001: 397-398). Como vemos, Deus assume uma configuração tipicamente dionisíaca, incentivando a personagem não a agir de acordo com os preceitos morais, mas sim pelos próprios instintos. A propósito, esse sonho parece representar uma ordem para que Nhô Augusto parta em busca da sua "hora", o que, de fato, o faz. Antes da partida, sentia que "a força da vida nele latejava, em ondas largas, numa tensão reconfortante, que era um regresso e um ressurgimento." (RosA 2001: 398). Esse paradoxo entre regresso e ressurgimento remete ao equilíbrio entre os impulsos apolíneo e dionisíaco, marcante em sua terceira e última fase.

\section{Augusto Matraga e o estabelecimento do trágico}

O equilíbrio entre os estados apolíneo e dionisíaco é revelado no modo despreocupado como Nhô Augusto parte em busca de sua libertação: ele parecia haver recuperado a sua força, mas não pretendia retornar ao seu primeiro estágio; preferia continuar à procura da sua "hora". Guiado por um jegue, parava a todo momento para contemplar a natureza e interagir com ela, tal qual um animal que, depois de preso durante muito tempo, é reinserido em seu habitat natural. Ele se reintegrava, assim, a essa natureza, trazendo à tona seus instintos dionisíacos, os quais tinham assumido uma feição apolinizada. E assim seguia o seu destino, sem se apressar, e "quando o jegue empacava [...] Nhô Augusto ficava em cima, mui concorde, rezando o terço, até que o jerico se decidisse a caminhar outra vez" (RoSA 2001: 404).

E nesse ritmo ele é conduzido ao arraial do Rala-Coco, muito próximo ao Murici, onde se deparou com um grande tumulto, ocasionado pela presença da jagunçada de Joãozinho Bem-Bem. Este último estava à espera de um homem cujo filho 


\section{Gregório, P. H. S. - O trágico em "Augusto Matraga"}

havia matado um de seus jagunços, o Juruminho, e, por esse motivo, segundo a lógica do chefe, era questão de honra vingar o companheiro. Como o matador havia fugido, restava à família pagar pelo crime. Em meio a toda essa confusão, Nhô Augusto foi recebido por Bem-Bem na fazenda em que estava hospedado, demonstrando grande satisfação por estar novamente na companhia daquela figura que tanto admirava. Nessa ocasião, o chefe dos jagunços aproveitou para questionar mais uma vez o comportamento beato do outro, atuando como uma força perturbadora do equilíbrio em que o "mano velho" se encontrava. Como homem dionisíaco, Joãozinho Bem-Bem, penetrando com olhar profundo na essência de Nhô Augusto, sabia que por trás daquela santidade toda havia um homem instintivo, valente.

Mais uma vez, ele convida Nhô Augusto a se tornar um de seus jagunços, para ocupar o lugar de Juruminho, atiçando, assim, os instintos dionisíacos do "mano velho". $\mathrm{Na}$ fase em que este se encontrava, com seus impulsos em estado de equilíbrio, um chamado dessa natureza "estava sendo a maior das suas tentações” (ROSA 2001: 407). Era como se o espírito de Dioniso estivesse a ser convocado a ressurgir e subjugar o apolíneo, o que faria a personagem renunciar ao ideal de salvação para se entranhar novamente no caos dionisíaco. Sendo assim, todo o tempo dedicado à vida de penitência, de isolamento, esforçando-se constantemente para não pensar em vingança, trabalhando e rezando sem cessar, em nome daquele ideal, tudo isso teria sido em vão. Era preciso decidir entre seguir o chefe e, assim, poder viver "no bom", sem se preocupar com a salvação da alma, ou continuar à procura de sua "hora" e "vez".

Embora dispondo dessas duas alternativas, completamente excludentes, Nhô Augusto estava decidido a persistir no seu ideal de libertação, e, desse modo, comunica sua decisão ao chefe do grupo: “- Não posso, meu amigo seu Joãozinho Bem-Bem!... Depois de tantos anos... Fico muito agradecido, mas não posso, não fale nisso mais..." (RoSA 2001: 407). Parecia doloroso ter de tomar aquela decisão, pois sabia que estava desperdiçando a oportunidade de se utilizar livremente da força da vida que latejava em seu ser. Mas era preferível manter sua essência dionisíaca sob o véu apolíneo da aparência, pois era nesse equilíbrio de forças que a personagem alcançaria sua redenção.

O prenúncio do fim da trajetória de busca empreendida por Nhô Augusto se dá quando, em defesa do pai do assassino de Juruminho, ele desafia o companheiro 


\section{Gregório, P. H. S. - O trágico em "Augusto Matraga"}

Joãozinho Bem-Bem, que havia renegado a intercessão do "mano velho" em favor daquele pai: “- Pois então... - E Nhô Augusto riu, como quem vai contar uma grande anedota..- Pois então, meu amigo seu Joãozinho Bem-Bem, é fácil... Mas tem que passar primeiro por riba de eu defunto...” (ROSA 2001: 409). Nesse momento, seus instintos dionisíaco e apolíneo passam a se manifestar simultaneamente, numa igualdade de forças, impulsionando as ações da personagem. Dionisiacamente ele se dispunha a confrontar com o chefe dos jagunços, expressando a sua valentia e força; regido pela moral apolínea, não compactuava com o desejo de vingança do companheiro, impondo-se para defender o homem, que havia clamado em nome de Jesus Cristo e da Virgem Maria. Tomada a resolução, ele anuncia o início do confronto: “- Epa! Nomopadrofilhospritossantamêin! Avança, cambada de filhos-da-mãe, que chegou a minha vez!...” (RosA 2001: 410).

Depois que invoca proteção da santíssima trindade, ele se utiliza de uma expressão chula para se referir a Bem-Bem e seus jagunços, revelando-se sob a ação das forças apolínea e dionisíaca, respectivamente. Mas é sob a atuação da primeira que ele permanece durante o confronto, no fim do qual, com o corpo todo atingido por balas, fere mortalmente com a faca Joãozinho Bem-Bem, de modo que "um mundo de cobras sangrentas" (RoSA 2001: 411) emergiu de seu corpo, fazendo-o cair ajoelhado. Quando já estão prestes a morrer, perdoam-se mutuamente, estabelecendo um pacto de amizade, conforme verificamos neste trecho:

- Estou no quase, mano velho... Morro, mas morro na faca do homem mais maneiro de junta e de mais coragem que eu já conheci!... Eu sempre lhe disse que era bom mesmo, mano velho... É só assim que gente como eu tem licença de morrer... Quero acabar sendo amigos...

- Feito, meu parente, seu Joãozinho Bem-Bem. Mas, agora, se arrepende dos pecados, e morre logo como um cristão, que é para a gente poder ir juntos... (ROSA 2001: 411).

Assim, a "hora" e a "vez" da personagem representam, ao mesmo tempo, aniquilamento e redenção. Libertar-se não poderia significar outra coisa senão a morte, pois só por meio desta é que o herói poderia restituir o que havia nele de mai essencial: o sentimento de supremacia inerente à sua individualidade, ao qual precisou renunciar 


\section{Gregório, P. H. S. - O trágico em "Augusto Matraga"}

durante a fase que denominamos apolínea. Continuar a viver significaria estar sempre fugindo do passado que tanto lhe trouxe desgraças e perdas, e essa fuga representaria uma negação da sua própria essência dionisíaca. Em contrapartida, por meio da morte ele estaria se lançando em um mundo no qual, provavelmente, não precisaria mais se esconder, reintegrando-se, por fim, à sua natureza. Mas o modo como se daria essa morte é que determinaria a "hora" e a "vez" da personagem aqui na terra, e por isso ele soube esperar o momento em que, trazendo à tona os seus instintos dionisíacos, morreria para salvar a vida de um homem, em convergência com a faceta apolínea de sua individualidade. MACHADO (1999: 25), referindo-se à tragédia segundo Nietzsche, afirma que esta representa o conflito "entre o principium individuationis e o uno originário; ou, mais precisamente, ela representa a derrota do saber apolíneo e a vitória do saber dionisíaco na medida em que faz da individuação um mal e a causa de todo sofrimento.” O próprio NIETZSCHE (apud MACHADO 1999: 25) assinala que

\footnotetext{
Para o herói trágico é necessário perecer, por onde ele deve vencer. Nessa antítese, que faz pensar, nós pressentimos a suprema avaliação da individuação [...]: o Uno originário tem necessidade dela para atingir o fim último de seu prazer, de modo que o desaparecimento se torna tão digno e venerável quanto o nascimento e que aquilo que nasceu deve cumprir, com o desaparecimento, a tarefa que lhe incumbe como individualidade.
}

Assim, a libertação da personagem se dá pelo viés do trágico, ou seja, ela atinge a sua "hora" e "vez" quando se encontra sob a ação equilibrada do apolíneo e dionisíaco, equilíbrio esse no qual reside a essência do trágico, segundo a concepção nietzschiana. De acordo com esta, a "tragédia não produz sofrimento mas alegria: uma alegria que não é mascaramento da dor, nem resignação, mas a expressão de uma resistência ao próprio sofrimento" (MACHADO 1999: 25). Nesse sentido, a morte de Nhô Augusto representa seu triunfo diante do sofrimento de ter que renunciar aos seus instintos dionisíacos em nome de um ideal de salvação, o qual não era inerente à essência do seu ser, configurando-se, ao que parece, como um pretexto para que ele pudesse ver recuperada a honra, a sua posição inicial. Nos últimos instantes de vida, fez questão de proclamar, com o rosto radiante: “- Perguntem quem é aí que algum dia já ouviu falar no nome de Nhô Augusto Esteves, das Pindaíbas!” (RosA 2001: 412). Parecia que a 


\section{Gregório, P. H. S. - O trágico em "Augusto Matraga"}

grande recompensa para a personagem seria a aclamação por parte das pessoas, o reconhecimento do seu ato, como se por meio disso sentisse a restituição completa de sua "homência", seu prestígio, tal qual um retorno ao uno primordial. O próprio lugar onde ocorre o desfecho da narrativa, no povoado próximo ao Murici, onde ela havia se iniciado, pode remeter a essa ideia do retorno.

MACHADO (1999: 26) assinala que a visão trágica do mundo nietzschiana "é um equilíbrio entre a ilusão e a verdade, entre a aparência e a essência: o único modo de superar a oposição metafísica de valores." Isso parece corroborar a ideia de se associar a trajetória da personagem à questão do trágico, tendo em vista o conflito que ela vivencia entre a essência dionisíaca e o mundo da aparência apolíneo, bem como o resultado desse jogo dual, ou seja, a redenção. Nesse sentido, o trágico, conforme vimos, é sinônimo de libertação para Nhô Augusto, o qual, depois do seu declínio, não visualizava qualquer possibilidade de voltar a ser o que fora outrora, o Augusto Esteves das Pindaíbas, e só por meio de outro viés é que poderia conquistar uma nova ascensão. Assim, a fase apolínea foi fundamental para que o instinto dionisíaco, responsável pela decadência da personagem, assumisse uma nova feição, apolinizada, e o resultado desse entrecruzamento de forças, a morte, tornou-se motivo de gozo, como podemos perceber neste fragmento: "Então, Augusto Matraga fechou um pouco os olhos, com sorriso nos lábios lambuzados de sangue, e de seu rosto subia um sério contentamento." (RosA 2001: 413). Segundo SPERBER (1982: 37, grifo da autora), "Matraga recobra um nome; realiza-se em termos nacionais: macho, guerreiro valente e combativo [...]. É a unidade reconquistada."

Rosa, em entrevista concedida a Ascendino Leite, afirma: "O que me interessa, na ficção, primeiro que tudo, é o problema do destino, sorte e azar, vida e morte" (apud DIJCK 1997: 55). E esses aspectos não deixam de estar presentes em "A hora e a vez de Augusto Matraga", conto em que o autor, ao trazer à tona o jogo entre essência e aparência, acaba por representar a tragédia da vida humana, o eterno conflito de forças com que o ser humano normalmente se depara, precisando escolher entre certo ou errado, bem ou mal, orientado por forças apolíneas e dionisíacas. Muitas vezes, dada a impossibilidade de escolha, vê-se obrigado a se apegar à única opção restante, embora precise fugir de sua essência e se revestir do véu da aparência. Assim, muito mais do 


\section{Gregório, P. H. S. - O trágico em "Augusto Matraga"}

que contar uma história, Rosa, nesse conto, representa algo inerente ao homem, fazendo com que a experiência de leitura possa funcionar como um verdadeiro convite ao leitor a refletir sobre a própria existência.

\section{Referências bibliográficas}

Albergaria, Consuelo. O sentido do trágico em "A terceira margem do rio". In: Coutinho, F. Eduardo (Org.). Guimarães Rosa. Rio de Janeiro, Civilização Brasileira, 1991, 520-526.

BenCHIMOL, Márcio. Apolo e Dionísio: arte, filosofia e crítica da cultura no primeiro Nietzsche. São Paulo, Annablume; Fapesp, 2002.

BRANDÃo, J. S. Teatro grego: tragédia e comédia. Petrópolis, Vozes, 1985. . Mitologia grega. Petrópolis, Vozes, 1991.

Bussolotti, Maria A. F. Marcondes (Org.). João Guimarães Rosa: correspondência com seu tradutor Curt Meyer-Clason (1958-1967). Tradução de Erlon José Paschoal. Rio de Janeiro: Nova Fronteira; Belo Horizonte: UFMG, 2003.

CAndido, Antonio. Sagarana. In: Coutinho, F. Eduardo (Org.). Guimarães Rosa. Rio de Janeiro, Civilização Brasileira, 1991, 243-247.

ChIAPPINI, Lígia. Entrevista: Curt Meyer-Clason. Scripta, 5 (10), 2002, 369-378.

CostA, Ana V. B. O mito em "A hora e a vez de Augusto Matraga” de João Guimarães Rosa. Dissertação de mestrado. FFLCH/USP, São Paulo, 2006.

DiJcK, Sônia Maria van (Org.). Ascendino Leite entrevista Guimarães Rosa. João Pessoa: Universitária, 1997.

FINAZZI-AGRÒ, Ettore. Aporia e passagem: a sobrevivência do "trágico" em Guimarães Rosa. Scripta, 5 (10), 2002, 122-128.

LEITÃo, Eduardo J. P. S. Augusto Matraga: um herói além do bem e do mal - uma perspectiva trágico-ontológica. 2006. 233f. Dissertação de Mestrado. PPgEL/ UFRN, Natal, 2006.

LESKY, Albin. A tragédia grega. Tradução J. Guinsburg et al. São Paulo, Perspectiva, 1976.

Lima, Márcio José Silveira. As máscaras de Dioniso: filosofia e tragédia em Nietzsche. São Paulo: Discurso Editorial; Ijuí: UNIJUÍ, 2006.

LoRenZ, Günter. Diálogo com Guimarães Rosa. In: CoutinHo, F. Eduardo (Org.). Guimarães Rosa. Rio de Janeiro, Civilização Brasileira, 1991, 62-97.

MACHADO, Roberto. A arte trágica e a apologia da aparência. In: Nietzsche e a verdade. São Paulo, Paz e Terra, 1999, 17-28.

. Zaratustra, tragédia nietzschiana. Rio de Janeiro, Jorge Zahar Ed., 2001.

. Arte, ciência, filosofia. In: MACHADO, R. (Org.). Nietzsche e a polêmica sobre

O nascimento da tragédia. Rio de Janeiro: Jorge Zahar, 2005, 7-34.

NiETZSCHE, Friedrich. O nascimento da tragédia, ou Helenismo e pessimismo. Tradução J. Guinsburg. São Paulo, Companhia das Letras, 1992. 
Gregório, P. H. S. - O trágico em "Augusto Matraga"

ORIONE, Eduino J. de Macedo. O drama barroco em "A terceira margem do rio". In: Ângulo 115, Lorena, 2008, 67-72. http://www.fatea.br/seer/index.php/angulo/article/view/99/86 (27/10/2010).

PERrusi, M. S. Nietzsche, pensador do trágico. In: Revista Symposium (1), 2000, 5-12.

RosA, João Guimarães. A hora e a vez de Augusto Matraga. In: Sagarana. Rio de Janeiro, Nova Fronteira, 2001, 363-413.

SPERbER, Suzi Frankl. Sagarana. In: Guimarães Rosa: signo e sentimento. São Paulo: Ática, 1982.

Recebido em 01/10/2010

Aprovado em 13/10/2010 